\title{
Pediastrum Meyen sensu lato (Chlorophyceae) in the phytoplankton of lowland and upland water bodies of Central Europe (Poland)
}

\author{
Joanna LENARCZYK
}

Department of Phycology, W. Szafer Institute of Botany, Polish Academy of Sciences, Lubicz 46, PL-31-512

Kraków, Poland, e-mail: j.lenarczyk@botany.pl

\begin{abstract}
Thirteen species and thirteen varieties of microscopic green algae from the genus Pediastrum were found in thirty one localities scattered in lowland and upland water bodies in Poland. Seven groups of localities are distinguished with cluster analysis. The groups differ from each other in terms of Pediastrum communities and environmental variables ( $\mathrm{pH}$, conductivity, carbonate hardness, nitrate and orthophosphate concentrations). The most distinct group contains five coastal lakes, which have high $\mathrm{pH}$ values and chloride concentration. Because the lakes have a high number of taxa, including a few rarely occurring worldwide, they are considered a hot spot for Pediastrum. Redundancy analysis revealed that the environmental variables account for ca thirty per cent of the variability of Pediastrum occurrence. Conductivity and $\mathrm{pH}$ statistically significantly explain the taxonomical variation of Pediastrum species and varieties. The genus Pediastrum as a whole is most positively correlated with conductivity. Individual taxa are influenced by different variables, except for $P$. tetras which is indifferent to them. The environmental preferences of the taxa can make inference on conditions in both recent and past water bodies more reliable.
\end{abstract}

Keywords: bioindicator, Central Europe, Chlorophyceae, cluster analysis, detrended correspondence analysis, ecology, green algae, Pediastrum, redundancy analysis

\section{INTRODUCTION}

Pediastrum Meyen (Chlorophyceae, Sphaeropleales, Hydrodictyaceae) is a genus of microscopic coccoid green algae living in aquatic habitats. It occurs in the form of flat aggregations composed of $2^{\mathrm{n}}$ cells; usually 16 or 32 cells. Such an aggregation is called coenobium, because all its cells originate from a single maternal cell. The cells are all of the same age and their number does not change after the coenobium forms (Komárek \& FotT 1983). Pediastrum coenobia are usually round with radially oriented marginal cells having processes of various length and shape.

Because of its distinctive shape resembling a star, as well as frequent occurrence in the plankton of stagnant waters, Pediastrum is well known to most phycologists. It is usually recorded from freshwater ponds and lakes, but occasionally also from brackish and salty waters. It lives mainly in eutrophic biotopes, but some its taxa occur at lower trophy or even dystrophy. It has been observed in rivers and on wet rocks as well (PARRA 1979, KowalsKa \& WoŁowsKi 2010B, KomÁreK \& JANKovSKÁ 2001).

Twenty six Pediastrum species have been described so far. Most of them were published in the mo- nograph by KOMÁREK \& JANKOVSKÁ (2001), two others, $P$. aniae found in Cuba (ComAs GonzÁlez 2005) and $P$. willei found in Spain (Comas GonzÁlez et al. 2006), can be added to the list of Pediastrum species. Recently, a new taxonomical system consisting in a separation of a few genera, e.g. Parapediastrum E. Hegewald, $L a-$ cunastrum McManus, Monactinus Corda and Stauridium CoRDA, from the genus Pediastrum has been proposed on the basis of phylogenetic studies. Some new species and nomenclatural combinations have been described as a result of these studies (Buchнеim et al. 2005; McManus \& Lewis 2011; McManus et al. 2011; Jena et al. 2014). However, the taxonomic system for Pediastrum in the present study follows KoméreK \& JANKOVSKÁ (2001). The reason is that only selected taxa have been subjected to the phylogenetic studies so far and the new system is still incomplete.

Some Pediastrum species, e.g. P. boryanum (Turp.) Menegh., $P$. duplex Meyen and $P$. tetras (Ehr.) RALFs, are cosmopolitan, but most of them, e.g. P. argentinense Bourr. et Tell, P. kawraiskyi Schmidle and P. tricuspidatum ConR., are known only from very distant localities and have restricted distribution. Despite its wide distribution, the genus Pediastrum probably has a decreasing evolutionary trend. Some of the rarely 
occurring species were more commonly distributed in the Late Glacial and Holocene (KOMÁREK \& JANKOVSKÁ 2001).

Because the cell wall of Pediastrum contains algaenans, which are biopolymers resistant to degradation (BLOKKER et al. 1998), empty coenobia have been frequently found in lake sediments formed in the Quaternary or even earlier. Subfossil Pediastrum species have been recorded by, e.g. Whiteside (1965), Sebestyén (1968), Jankovská \& KomÁrek (1982, 1995), Nielsen \& Sørensen (1992), Wolowski et al. (2002), Sarmaja-Korjonen et al. (2006), Wacnik (2009), Święta-Musznicka et al. (2011). KomÁreK \& JANKOVSKÁ (2001) concluded that analyses of the whole Pediastrum communities are more reliable for deducting on ecological conditions in past water bod- ies than analyses of single species. Recent studies on modern Pediastrum taxa also revealed their potential as paleobioindicators (WECKSTRÖM et al. 2010; WHITNEY \& MAYLE 2012).

There is a number of studies devoted to environmental preferences of modern Pediastrum taxa. However, the preferences of most taxa, especially those at the intraspecific level, have not been sufficiently recognized so far or differ depending on author. SULEK (1969) gave information on the frequency of occurrence of Pediastrum species. PARRA (1979) described requirements of individual species and varieties towards $\mathrm{pH}$. More information on distribution, type and trophy of water bodies, affinity for plankton, benthos and periphyton communities were given by KOMÁREK \& FOTT (1983) and KomÁREK \& JANKOVSKÁ (2001). The authors pointed out that the ecological preferences of some

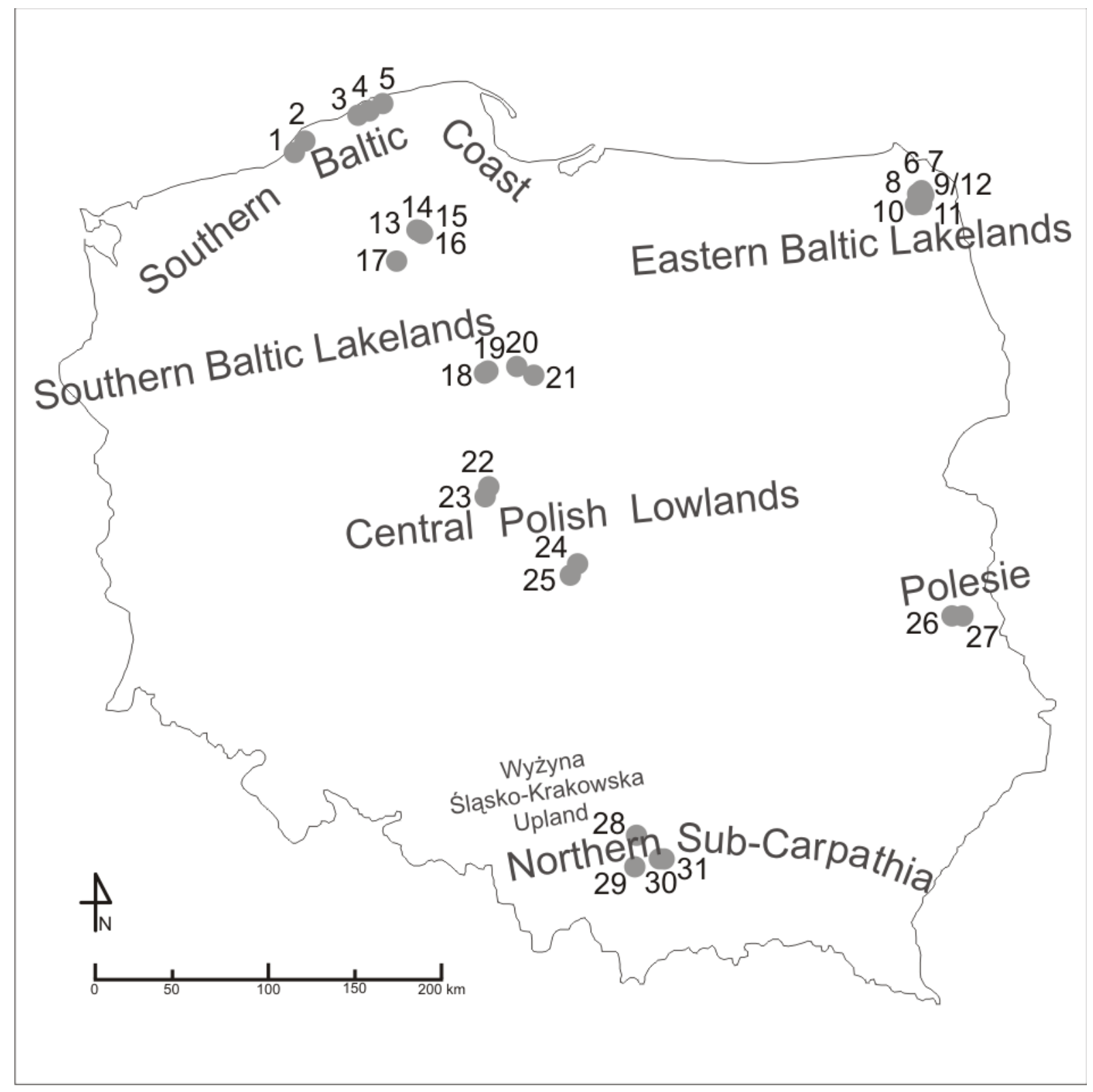

Fig. 1. Localities in Poland on map of physiographic units (subprovinces). 
taxa, e.g. $P$. asymmetricum Hegew. et Yamag., $P$. boryanum var. pseudoglabrum PARRA and $P$. duplex var. asperum (A. BR.) HANSG., are questionable or not well known due to their rare occurrence or misidentification. Some papers deal with Pediastrum from specific geographical regions. TeLL (2004) revised both modern and subfossil findings of Pediastrum from Argentina and summarized their characteristics like the frequency of occurrence, geographical distribution and ecology. WeCKSTRÖM et al. (2010) are the only one who used multivariate statistical analyses in order to identify the influence of several environmental variables on the occurrence of Pediastrum. However, their study was restricted to some subarctic lakes in Finnish Lapland.

The aim of the present study was to identify the influence of environmental variables on the occurrence of Pediastrum in the inshore phytoplankton of lowland and upland water bodies in Poland. These variables were $\mathrm{pH}$, conductivity, carbonate hardness, nitrate and orthophosphate concentrations. In order to link the $\mathrm{Pe}$ diastrum taxa and communities to their environment, multivariate analyses were performed on the author's own dataset published elsewhere (LENARCZYK 2014).

\section{Materials and Methods}

Field and laboratory works. The material was collected from single localities (as exception from two localities in Lake Wigry) situated in thirty water bodies scattered in the lowland and upland regions of Poland. The study covered seven physiographic units called subprovinces, including Southern Baltic Coast, Eastern and Southern Baltic Lakelands, Central Polish Lowlands, Polesie, Wyżyna ŚląskoKrakowska Upland and Northern Sub-Carphatia (Fig. 1). Detailed information on these subprovinces can be found in KonDRACKI $(1994,2002)$. Various types of water bodies were sampled: coastal lakes (5), lowland lakes with a forest (5) and mixed (8) catchment, fish (4), field (1), park (3), suburban (1) and village (1) ponds, as well as a peat pit and an oxbow lake (Table 1). This classification follows LENARCZYK (2014). Inshore samples were taken with a plankton net no. 25 in the vegetation seasons (between June and September) of 2008 and 2009. Water temperature, $\mathrm{pH}$, conductivity, carbonate hardness, nitrate and orthophosphate concentrations were measured at each locality during sample collection (Table 1). For each sample, the per cent shares of the genus Pediastrum as a whole and all its species within the total number of planktonic algae were estimated on a 3-degree scale as follows: $\leq 3 \%, 4-10 \%, 11-25 \%$; higher shares were not observed (Table 2). Because of difficulties in determining some specimens belonging to $P$. biradiatum, $P$. boryanum, $P$. duplex and P. simplex under light microscope their shares in algal communities were not estimated (Table 3). Further details regarding material collection and elaboration can be found in LENARCZYK (2014).

Statistical analyses. Comparison of the localities with regard to the presence of Pediastrum taxa was computed using the Jaccard coefficient and visualized as a classification dendrogram (Fig. 2) based on the paired group algorithm as a similarity measure in the Past program, ver. 2 (HAMmer et al.
2001). The occurrence of the taxa was marked as " 1 ", their absence was marked as " 0 ".

In order to estimate the relationships between the occurrence of Pediastrum and the environmental variables, $\mathrm{pH}$, conductivity, carbonate hardness, nitrate and orthophosphate concentrations, a redundancy analysis (RDA) was preformed with the CANOCO program, ver. 4.53 (TER BRAAK $\&$ Śmilauer 2002). The analysis on the genus Pediastrum as a whole and its species (Fig. 3) was run separately from the analysis on $P$. biradiatum, $P$. boryanum, $P$. duplex and $P$. simplex varieties (Fig. 4), because the shares of the varieties within planktonic algae were not estimated. While the shares of the genus Pediastrum as a whole and its species were transformed as follows: $\leq 3 \%-" 1 ", 4-10 \%-" 2 "$, $11-25 \%$ - " 3 ", the occurrence of the varieties was marked as " 1 ", their absence was marked as " 0 ". The RDA was selected on the basis of the length of the environmental gradient (shorter that 3 standard deviation units) obtained in a detrended correspondence analysis (DCA) with detrending by segments, without transformation of species and varieties data and without downweighting of rare taxa. The RDA was run with the following options: focus scaling on inter-species correlations, species scores divided by standard deviation, no transformation of species data, centering by species. The analysis of the relationships between the genus Pediastrum, its species and the environmental variables was conducted for 31 localities, whereas the analysis of the relationships between the varieties and the variables were performed for 28 localities, omitting those where the varieties were not found. Conductivity values were $\log _{10}$ transformed prior to the analyses because of their skewness. Nitrate and orthophosphate values under detection levels were replaced with " 2.5 " and " $0.075 "$, respectively. Automatic forward selection was used to assess the relative value of each environmental variable in describing the variability of Pediastrum occurrence. Monte Carlo permutation test (499 unrestricted permutations, $P \leq$ 0.05 ) was performed to verify which environmental variables statistically significantly explain the taxonomical variation in the analyzed data sets. RDA diagrams were plotted on the first and second ordination axes.

\section{RESUltS}

Thirty water bodies analyzed in the present study varied with respect to morphometry, catchment, trophy and physicochemical water parameters. Among them, there were ponds having less than 1 ha and larger water bodies, up to more than 2000 ha. They had a manmade, forest or mix catchment and ranged from oligo/mesotrophic to eutrophic; one lake was humoeutrophic. Their water temperature varied from $15.7^{\circ} \mathrm{C}$ to 25.0 ${ }^{\circ} \mathrm{C}$. All water bodies were alkaline; $\mathrm{pH}$ values were 7.4-9.6. The range of conductivity was broad, 46-1740 $\mu \mathrm{S} . \mathrm{cm}^{-1}$. Carbonate hardness varied from $1.2^{\circ} \mathrm{n}$ to $15.6^{\circ} \mathrm{n}$. Nitrate concentration was below the threshold of detection of $5 \mathrm{NO}_{3}^{-} \mathrm{mg} \cdot \mathrm{dm}^{-3}$ in most of the water bodies studied; higher values, 5, 10 and $20 \mathrm{NO}_{3}{ }^{-} \mathrm{mg}^{-\mathrm{dm}^{-3}}$, were noted in a few of them. Orthophosphate concentration varied between below than 0.15 (the threshold of detection) to $1.5 \mathrm{PO}_{4}{ }^{3-} \mathrm{mg} \cdot \mathrm{dm}^{-3}$ (Table 1). 


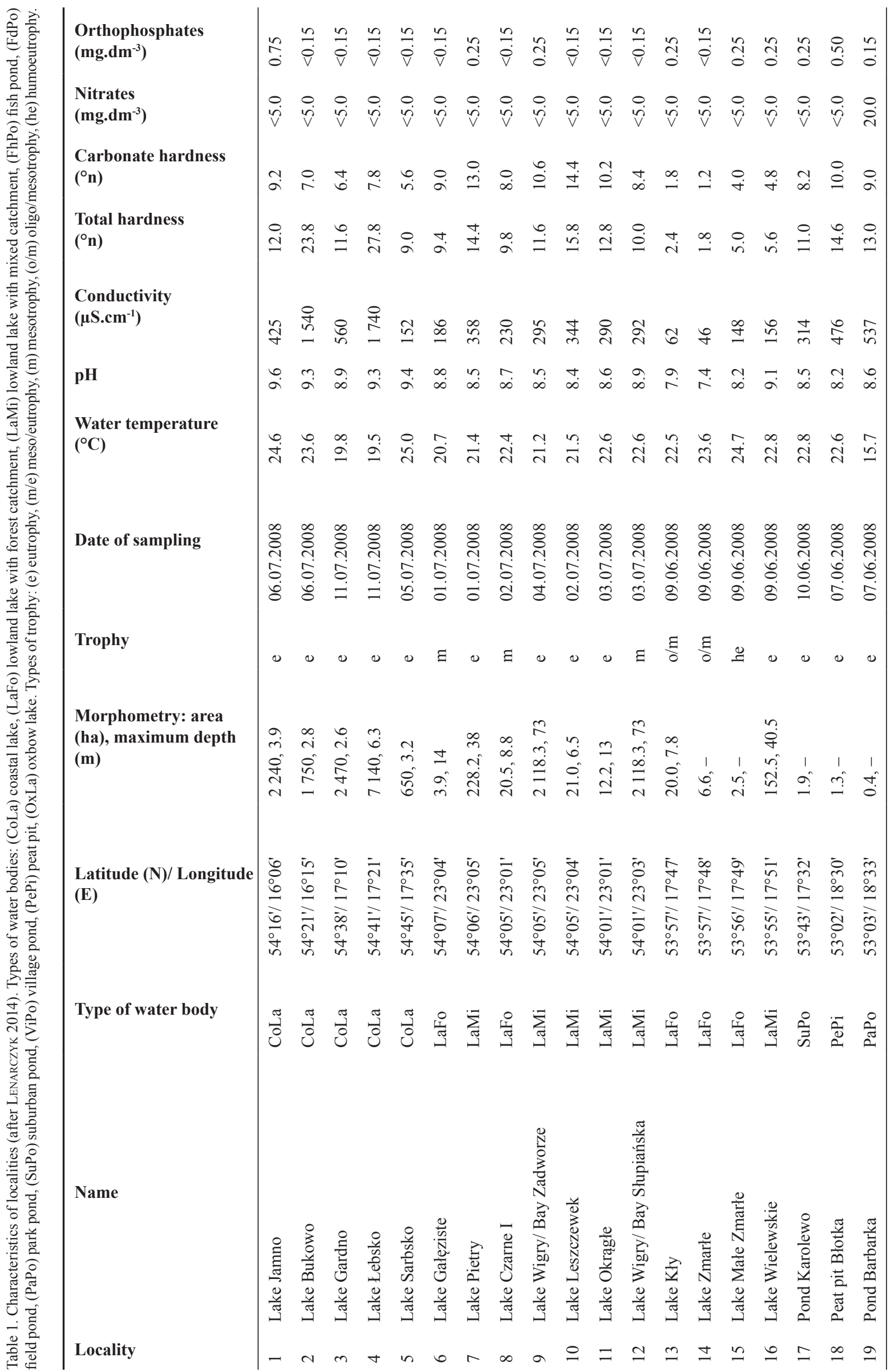




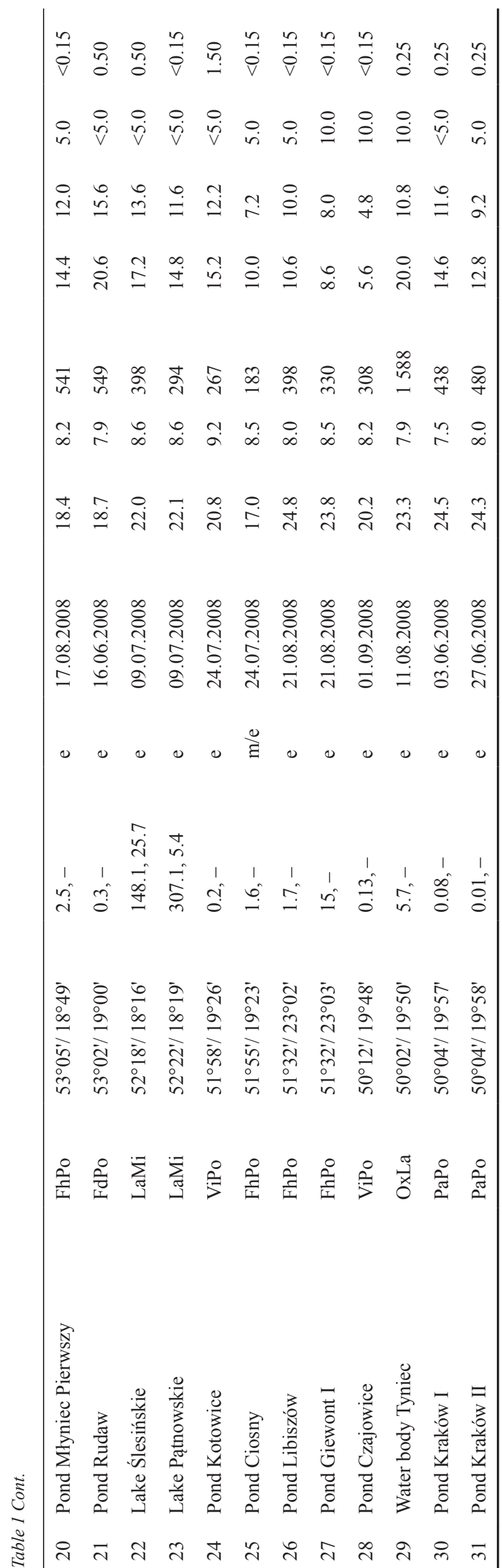

Altogether, thirteen Pediastrum species were observed in the water bodies studied. P. boryanum, P. duplex and P. tetras were most frequently found, at 29,18 and 18 localities, respectively. On the contrary, $P$. integrum, $P$. musteri, $P$. patagonicum, and $P$. privum occurred at single localities (Table 2). Additionally, thirteen varieties of $P$. boryanum (7), P. duplex (3), P. simplex (2) and $P$. biradiatum (1) were identified. Among them, $P$. boryanum varieties, boryanum, forcipatum and perforatum, were most frequently observed (at 19, 11 and 9 localities, respectively), whereas $P$. biradiatum var. biradiatum, $P$. boryanum var. brevicorne and $P$. boryanum var. cornutum were found at single localities (Table 3 ).

The genus as a whole and most of its species usually had a low share $(\leq 3 \%)$ in the algal communities. There were only six localities where Pediastrum had a share of $4-25 \%$. These were three coastal lakes, a suburban pond, a fish pond and an oxbow lake. Among Pediastrum species, the highest share belonged to $P$. simplex (11-25\%) in the oxbow lake mentioned and to P. boryanum (4-10\%) in one of the coastal lakes (Table 2).

All localities were compared with regard to the occurrence of Pediastrum taxa in the classification diagram. Seven groups of localities were distinguished. They were enumerated, starting with the most distinct group (Fig. 2). The first group comprises only two lakes (nos. 13 and 14) with low trophy and a forest catchment, situated in the Southern Baltic Lakelands. The lakes had low values of all physicochemical parameters measured (Fig. 2). Only P. angulosum var. angulosum was noted in the lake no. 13. Apart from this taxon, P. boryanum var. cornutum and P. tetras were found in the second lake. The second group consists of four mesotrophic and eutrophic localities situated in the Eastern Baltic Lakelands. They had alkaline pH (8.5$8.7)$, medium conductivity values $\left(230-358 \mu{\mathrm{S} . \mathrm{cm}^{-1}}^{-1}\right.$, low nitrates and orthophosphates $\left(<5.0 \mathrm{mg} \cdot \mathrm{dm}^{-3}\right.$ and $\leq 0.25 \mathrm{mg} . \mathrm{dm}^{-3}$, respectively), and carbonate hardness $8.0-13.0^{\circ} \mathrm{n}$. They distinguished themselves by the occurrence of a single taxon, $P$. boryanum var. perforatum, and exceptionally a taxon of $P$. duplex undetermined to the variety level at the locality no. 11 . The next group comprises five lakes and ponds from different regions of Poland where 2-3 taxa of $P$. boryanum and/or $P$. duplex and P. tetras or P. simplex occurred. The water bodies were mesotrophic and eutrophic and had broad ranges of most physicochemical parameters measured (Fig. 2). Similarly to the previous group, the fourth one consists of mesotrophic and eutrophic localities from different regions of Poland, which represent various environmental conditions; the $\mathrm{pH}$ values were ca 8.5 , conductivity $292-537 \mu{\mathrm{S} . \mathrm{cm}^{-1}}^{-1}$, nitrates $\leq 20.0 \mathrm{mg} . \mathrm{dm}^{-3}$ and orthophosphates $\leq 0.5 \mathrm{mg}$. dm ${ }^{-3}$. In this group, a low number of taxa (1-3) was also observed. The group is characterized by two $P$. boryanum varieties, boryanum and/or longicorne. At some localities, P. simplex var. echinulatum and $P$. duplex var. 
Table 2. Per cent shares of the genus Pediastrum as a whole and its species in algal communities (in systematic order according to KomÁrEK \& JANKOVSKÁ 2001) at localities.

\begin{tabular}{|c|c|c|c|}
\hline & $\leq \mathbf{3 \%}$ & $4-10 \%$ & $11-25 \%$ \\
\hline Pediastrum Meyen spp. & $1,5-16,18-24,26-28,30-31$ & $2-4,17,25$ & 29 \\
\hline P. simplex MEYEN & $18,20,22-24,26-27$ & & 29 \\
\hline P. musteri Tell et Mataloni & 4 & & \\
\hline P. patagonicum Tell et MATALONI & 27 & & \\
\hline P. kawraiskyi SCHMIDLE & $1-5$ & & \\
\hline P. orientale (SKUJA) JANKOVSKÁ et KOMÁREK & $2-4,27$ & & \\
\hline P. integrum NäGELI var. integrum & 15 & & \\
\hline P. boryanum (TURPIN) MENEGHINI & $1-3,5,7-12,14-31$ & 4 & \\
\hline P. duplex MEYEN & $1-6,11,15,17,20-26,29-30$ & & \\
\hline P. alternans NYGAARD & $1,3-5$ & & \\
\hline P. angulosum (EHRENBERG) MENEGHINI var. angulosum & $13-15$ & & \\
\hline P. privum (Printz) Hegewald & 15 & & \\
\hline P. tetras (EHRENBERG) RALFS & $2,4-6,10,14-17,20-21,24-30$ & & \\
\hline P. biradiatum MeYen & $3,17,25$ & & \\
\hline
\end{tabular}

Table 3. Occurrence of $P$. simplex, P. boryanum, P. duplex and $P$. biradiatum varieties (in systematic order according to KoMÁREK \& JANKOVSKÁ 2001) at localities.

\begin{tabular}{ll}
\hline P. simplex MEYEN var. simplex & $20,24,27,29$ \\
P. simplex var. echinulatum WittRock & $18,23,26-27,29$ \\
P. boryanum (TURPIN) MENEGHINI var. boryanum & $1-5,10,15,17-21,23-27,29,31$ \\
P. boryanum var. pseudoglabrum PARRA & $1,3-5,24,26,29$ \\
P. boryanum var. cornutum (RACIBORSKI) SULEK & 14 \\
P. boryanum var. perforatum (RACIBORSKI) NITARDY & $1,3,5,7-11,15-16,25$ \\
P. boryanum var. longicorne REINSCH & $3,5,12,15-17,25,31$ \\
P. boryanum var. brevicorne A. BRAUN & 1 \\
P. boryanum var. forcipatum (CORDA) CHODAT & $1,3-5,17,20,24,26,29$ \\
P. duplex MeYEN var. duplex & $3,21-22,29-30$ \\
P. duplex var. rugulosum RACIBORSKI & $2,4,15,17,25$ \\
P. duplex var. asperum (A. BRAUN) HANSGIRG & $25-26$ \\
P. biradiatum MeYEN var. biradiatum & 17 \\
\hline
\end{tabular}

indet. occurred. The group no. 5 comprises five lakes and ponds having various trophy (meso/eutrophic to humoeutrophic), located in the Eastern and Southern Baltic Lakelands and Central Polish Lowlands. The water bodies had low nitrates and orthophosphates ( $\leq 5.0 \mathrm{mg} . \mathrm{dm}^{-3}$ and $\leq 0.25 \mathrm{mg} . \mathrm{dm}^{-3}$, respectively). The ranges of the other physicochemical parameters measured were broad (Fig. 2). The number of taxa in the water bodies of this group was variable, from 3 to 8 . The occurrence of P. tetras and P. boryanum var. longicorne and/or $P$. boryanum var. boryanum was the common feature of this group. Additionally, other $P$. boryanum varieties including forcipatum, perforatum, pseudoglabrum, $P$. duplex varieties including asperum and rugulosum and other species, P. angulosum, $P$. biradiatum, $P$. integrum and $P$. privum, occurred in 
some of the water bodies. The sixth group consists of all five coastal lakes (Southern Baltic Coast) analyzed in the present study. The lakes are eutrophic, have high $\mathrm{pH}$ values (8.9-9.6), a broad range of conductivity values, from 152 up to $1740 \mu \mathrm{S} . \mathrm{cm}^{-1}$, and low nitrates $\left(<0.5 \mathrm{mg} \cdot \mathrm{dm}^{-3}\right)$. In contrast to the other water bodies, the coastal lakes were characterized by rich taxonomic composition (8-10 taxa, except no. 2, where only 5 taxa were observed). $P$. boryanum var. boryanum and P. kawraiskyi were found in all coastal lakes. P. alternans, $P$. boryanum varieties including forcipatum, perforatum and pseudoglabrum, $P$. orientale and P. tetras occurred in most of the lakes. The last group comprises eutrophic fish ponds, a village pond and an oxbow lake located in different Polish regions and strongly differing from one another with respect to environmental conditions (Fig. 2). Five to seven taxa were noted in each water body. P. boryanum var. boryanum, $P$. simplex (var. simplex and/or echinulatum) and $P$. tetras were common taxa for this group. Other $P$. boryanum varieties including forcipatum and pseudoglabrum, as well as various $P$. duplex varieties were found in most of the water bodies.

In redundancy analysis (RDA) of relationships between the genus Pediastrum as a whole, species and environmental variables $(\mathrm{pH}$, conductivity, carbonate hardness, nitrate and orthophosphate concentrations), the first two axes accounted for $17.1 \%$ (axis 1) and $9.3 \%$ (axis 2 ) of the variation of taxa composition, and $52.3 \%$ (axis 1) and $28.5 \%$ (axis 2) of the relationships between taxa composition and environmental variables. In RDA of relationships between $P$. biradiatum, $P$. boryanum, $P$. duplex and $P$. simplex varieties and the environmental variables mentioned above, the first two axes explained $13.2 \%$ (axis 1) and $8.9 \%$ (axis 2) of the variation of taxa composition, and $47.6 \%$ (axis 1) and $32.5 \%$ (axis 2) of the relationships between taxa composition and environmental variables. The variables accounted for $32.7 \%$ of variability of occurrence of the genus Pediastrum as a whole and its species, and $27.6 \%$ of occurrence of the varieties of the four species mentioned above. Among the environmental variables,

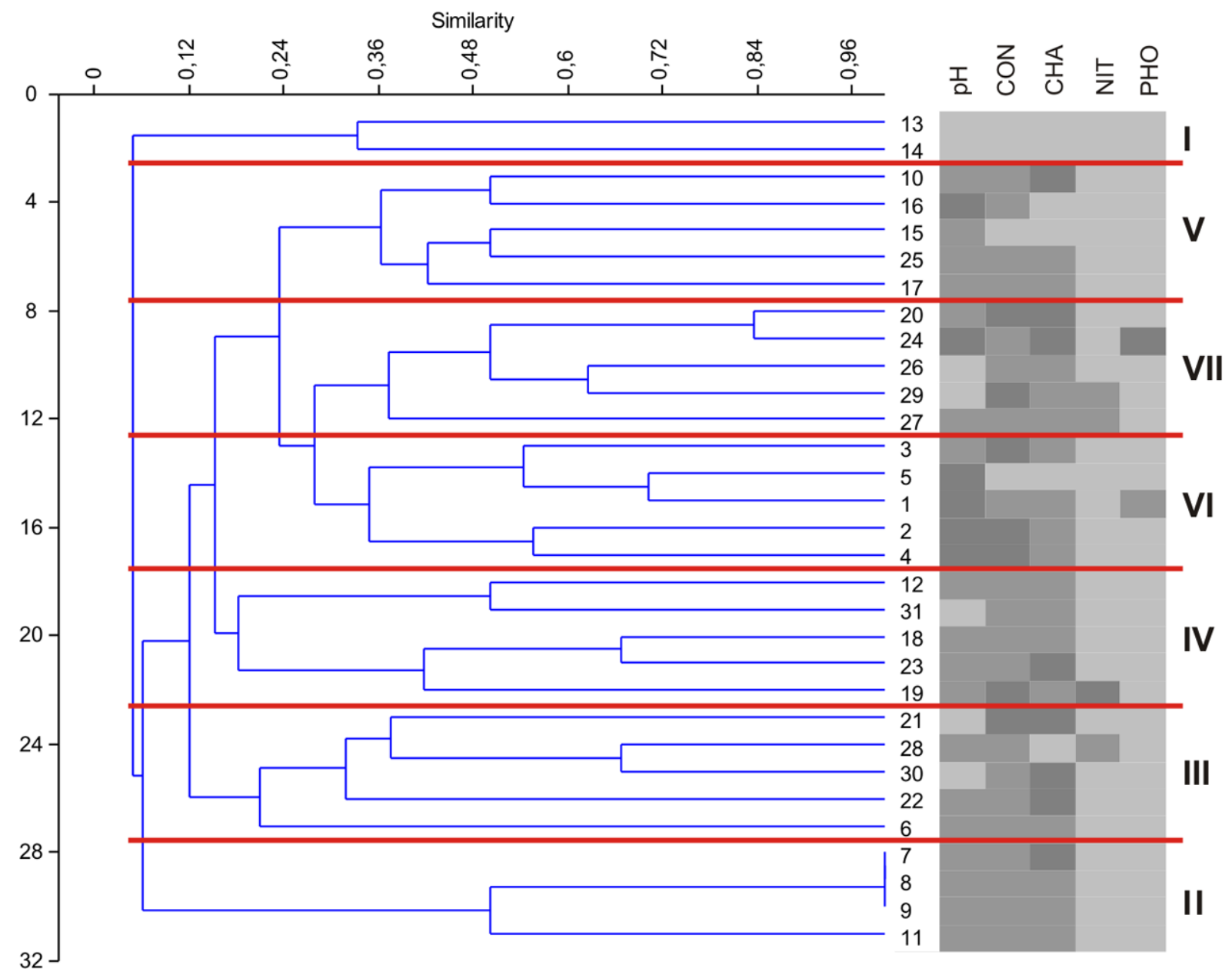

Fig. 2. Classification dendrogram of similarities between localities based on presence of Pediastrum taxa. Values of environmental variables divided on three groups marked with colours ( $\_, \ldots, \ldots$, respectively): $\mathrm{pH}(7.4-8.1,8.2-8.9,9.0-9.7)$, (CON) conductivity, 1.662-2.188, 2.189-2.715, 2.716-3.242, $\log _{10}$ transformed; (CHA) carbonate hardness, $1.1-5.9^{\circ} \mathrm{n}, 6.0-10.8^{\circ} \mathrm{n}, 10.9-15.7^{\circ} \mathrm{n}$; (NIT) nitrate concentration, 2.5-8.3 mg.dm ${ }^{-3}, 8.4-14.2 \mathrm{mg} . \mathrm{dm}^{-3}, 14.3-20.1{\mathrm{mg} . \mathrm{dm}^{-3}}^{-3}$ (PHO) orthophosphate concentration, $0.074-0.549 \mathrm{mg} . \mathrm{dm}^{-3}, 0.550-1.025 \mathrm{mg} . \mathrm{dm}{ }^{-3}$, $1.026-1.501 \mathrm{mg} \cdot \mathrm{dm}^{-3}$. 


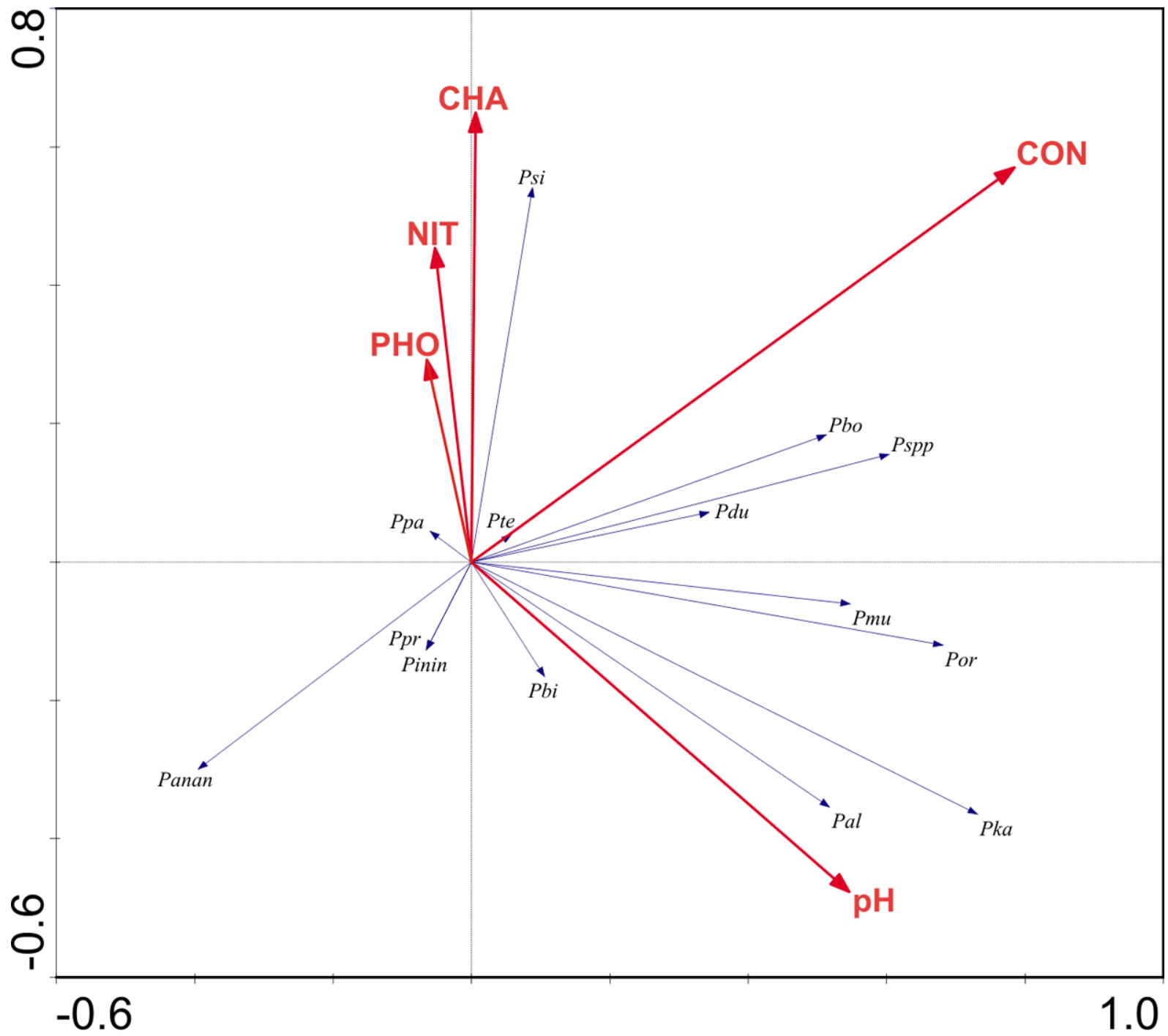

Fig. 3. RDA ordination biplot showing relationships between the genus Pediastrum as a whole, its species and environmental variables: $\mathrm{pH}$, conductivity (CON), carbonate hardness (CHA), nitrate (NIT) and orthophosphate (PHO) concentrations. Abbreviations of Pediastrum names: (Pal) P. alternans, (Panan) P. angulosum var. angulosum, (Pbi) - P. biradiatum, (Pbo) P. boryanum, (Pdu) P. duplex, (Pinin) P. integrum var. integrum, (Pka) P. kawraiskyi, (Pmu) P. musteri, (Ppa) P. patagonicum, (Ppr) P. privum, (Pspp) Pediastrum spp., (Psi) P. simplex, (Pte) - P. tetras. The eigenvalues of axis 1 (horizontally) and axis 2 (vertically) are 0.17 and 0.09 , respectively.

conductivity, $\mathrm{pH}$ and carbonate hardness were statistically significantly correlated with the occurrence of Pediastrum species and the genus a whole, explaining $14 \%, 7 \%$ and $7 \%$ of its variability, respectively, whereas conductivity and $\mathrm{pH}$ were statistically significantly correlated with the occurrence of Pediastrum varieties, explaining $9 \%$ and $8 \%$ of its variability, respectively. From the ordination plot of Fig. 3, it follows that the genus and its two most often found species, P. boryanum and $P$. duplex, were most strongly positively correlated with conductivity (upper right quadrant). However, intraspecific $P$. boryanum and $P$. duplex taxa showed different ecological preferences. The occurrence of $P$. boryanum varieties, var. boryanum, forcipatum and pseudoglabrum (upper right quadrant), was correlated with indicators of higher trophic conditions (orthophosphates and conductivity), whereas var. cornutum, perforatum and longicorne (left upper and lower quadrants) showed an affinity for lower trophy. Among $P$. duplex varieties, var. duplex (lower right quadrant) was correlated with high nitrate concentrations, whereas var. rugulosum (upper left quadrant) was correlated with high $\mathrm{pH}$ (Fig. 4). High $\mathrm{pH}$ values proved to influence also the occurrence of $P$. alternans and P. kawraiskyi (Fig. 3, lower right quadrant). Both $P$. simplex varieties, var. simplex and echinulatum (lower right quadrant), showed similar preferences towards higher values of nitrates, orthophosphates and other mineral compounds causing high conductivity and carbonate hardness (Fig. 4). On the contrary, P. angulosum (lower left quadrant) was negatively correlated with conductivity (Fig. 3). 


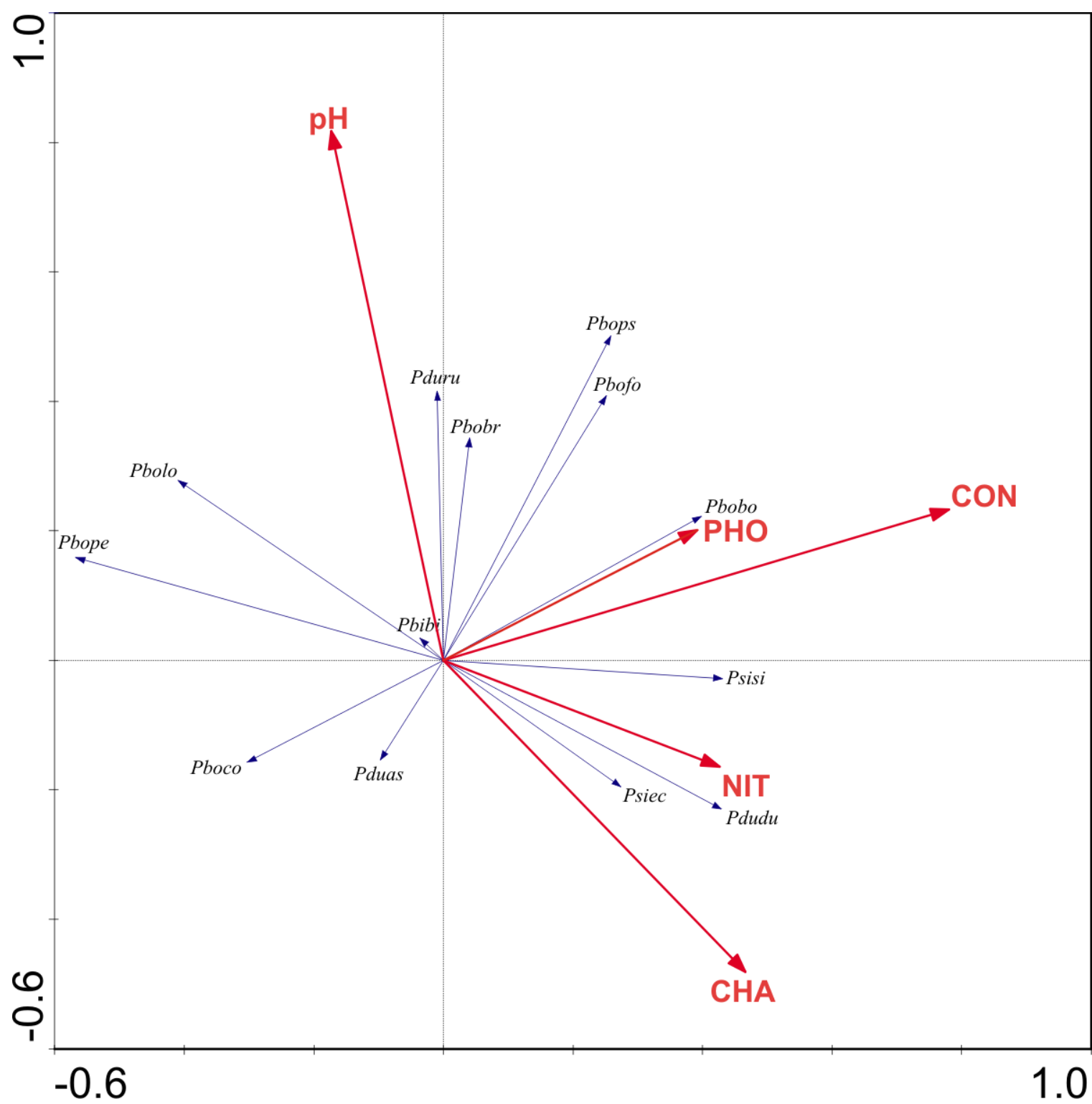

Fig. 4. RDA ordination biplot showing relationships between Pediastrum varieties and environmental variables: $\mathrm{pH}$, conductivity (CON), carbonate hardness (CHA), nitrate (NIT) and orthophosphate (PHO) concentrations. Abbreviations of Pediastrum names: (Pbibi) P. biradiatum var. biradiatum, (Pbobo) P. boryanum var. boryanum, (Pbobr) P. boryanum var. brevicorne, (Pboco) P. boryanum var. cornutum, (Pbofo) P. boryanum var. forcipatum, (Pbolo) P. boryanum var. longicorne, (Pbope) P. boryanum var. perforatum, (Pbops) P. boryanum var. pseudoglabrum, (Pduas) P. duplex var. asperum, (Pdudu) P. duplex var. duplex, (Pduru) P. duplex var. rugulosum, (Psiec) P. simplex var. echinulatum, (Psisi) $P$. simplex var. simplex. The eigenvalues of axis 1 (horizontally) and axis 2 (vertically) are 0.13 and 0.09 , respectively.

\section{Discussion}

The study was carried out in thirty water bodies (thirty one localities) representing a wide spectrum of lowland and upland habitats in Poland (Table 1, Fig. 1). Ecological preferences of Pediastrum, including thirteen out of nineteen species and thirteen out of seventeen varieties known from the country (LENARCZYK 2014), were analyzed.

Three species, which were most often found in the present study, P. boryanum, P. duplex and P. tetras, occur commonly worldwide (KoMÁREK \& JANKOVSKÁ 2001). They also are among the most variable species of the genus. Nine $P$. boryanum varieties and four $P$. duplex varieties were listed by KOMÁREK \& JANKOVSKÁ (2001). The authors stated that a few varieties of $P$. tetras described so far are questionable taxonomic units which need revision. The three species serve as examples of discrepancies between traditional taxonomy relying on morphological features and modern taxonomy based on molecular data. Recent phylogenetic studies reveled that strains exhibiting P. boryanum morphology do not form one clade and some of them are more closely related to $P$. angulosum or P. duplex (Buchinim et al. 2005; McManus \& Lewis 2011; JenA et al. 2014). McManus \& Lewis $(2005,2011)$ and MCMANus et al. (2011) observed that the morphological and genetical variability within $P$. duplex is so great 
that its strains form three distinct clades, of which one includes also a few morphologically different species, and another one comprises strains of $P$. duplex var. gracillimum (not analyzed in the present study), renamed as Lacunastrum gracillimum (W. West \& G.S. West) H. McManus. Similarly, some strains of $P$. tetras (as Stauridium tetras (EHR.) E. HeGEWALD) are more closely related to strains representing $P$. privum (as Stauridium privum (PRINTZ) E. HEGEWALD) than to the strains with the morphology typical of $P$. tetras (McManus \& LEWIS 2011). A thorough revision of Pediastrum based on both molecular and morphological data is necessary, especially for such morphologically variable species like $P$. boryanum or $P$. duplex. Until the revision is done, the species and varieties analyzed in the present study, especially those mentioned in this paragraph, should be considered morphological units.

All coastal lakes in the Southern Baltic Coast, which grouped together in the cluster analysis (Fig. 2), seem to be a hot spot for Pediastrum. This is shown by the highest number of taxa (usually 8-10) in the lakes compared to the others and the occurrence of rare Pediastrum species like P. alternans, P. kawraiskyi, . musteri and $P$. orientale. KOMÁREK \& JANKOVSKÁ (2001) suggested that $P$. alternans and $P$. kawraiskyi are relict species. P. alternans occurs in the Baltic Rim countries (NYGAARD 1949; KOMÁREK \& JANKOVSKÁ 2001; Kowalska \& WoŁowski 2010b). A record of $P$. alternans from Namibia given by JENA et al. (2014) should be revised due to morphological differences between the European and African specimens. According to KomÁreK \& JANKOVSKÁ (2001), P. kawraiskyi occurs sporadically in colder areas of the temperate zones, whereas $P$. orientale is known from distant localities. Besides the coastal lakes, a few other localities of $P$. alternans and $P$. orientale in Poland are in its central and eastern regions, and numerous localities of $P$. $k a$ wraiskyi are scattered in the whole country. P. musteri was more often found in both Americas (TELL \& MATALONI 1990; IZAGuirRe \& VinOCuR 1994; COMAS GONZÁlez \& Perez 2002; Tell 2004). In Poland, it is known from two localities close to the Baltic Sea (LENARCZYK 2014). Other species, $P$. argentinense Bour. et TELL (as synonym $P$. duplex var. cohaerens BoHLin) and $P$. obtusum LUCKS, which occur rarely worldwide (KomÁREK \& JANKOVSKÁ 2001), were found in Polish coastal lakes by Strzelecki \& PóŁtorak (1971) and Burchard et al. (2003). KowALSKA \& WoŁowsKi (2010b) assumed that coastal lakes are especially favourable for Pediastrum. LenARCZYK (2014) described the lakes as eutrophic and suggested that the inflow of saline seawaters enriches them with some mineral compounds influencing the growth of rare Pediastrum species. For example, chloride concentration in the lakes located along the southern coast of the Baltic Sea may reach up to $1000 \mathrm{mg} . \mathrm{dm}^{-3}$ (BURCHARDT et al. 2003; KowALSKA $\&$ WoŁowski 2010b). Other peculiarities of the lakes are small depths and relatively large areas (Table 1), which, together with the process of water mixing and the permanent accessibility of fast releasing nutrients, support the presence of high numbers and densities of green algae, like $P$. boryanum var. boryanum and $P$. kawraiskyi (BurchARDT et al. 2003). Similarly, P. boryanum reached its highest abundance in one coastal lake in the present study, however only $4-10 \%$ share in the algal community.

The low shares of the genus as a whole and its species in most algal communities under study show that Pediastrum does not cause water blooms. However, PARRA (1979) stated that under special undefined conditions (particularly in slightly eutrophic waters) some species, $P$. simplex, $P$. boryanum and $P$. duplex, can occur in such abundances that water becomes green. In the present study, the highest share (11-25\%) belonged to P. simplex in an oxbow lake, in southern Poland. The high share means that the species had good conditions for growth (compared to other algae) in this water body, which is relatively shallow, of alkaline $\mathrm{pH}$ and high conductivity, ca $1500 \mu \mathrm{S} . \mathrm{cm}^{-1}$ (LENARCZYK 2014).

In the redundancy analysis, conductivity, representing the total concentration of ions in the water, was the most statistically significant variable deciding on the occurrence of the genus Pediastrum as a whole and its species and varieties (Figs 3, 4). The genus was most strongly positively correlated with conductivity. This agrees with the conclusion of PARRA (1979), who pointed out that Pediastrum species are characteristic of the plankton of small, warm water bodies, usually rich in nutrients. Besides conductivity, $\mathrm{pH}$ was also statistically significantly correlated with the occurrence of the genus, species and varieties, and carbonate hardness, representing the amount of calcium and magnesium carbonates and bicarbonates, was statistically significantly influencing the occurrence of the genus and species. These variables explained ca thirty per cent of the variability of Pediastrum occurrence. Not only conductivity and $\mathrm{pH}$, but also dissolved organic carbon, water colour and precipitation were statistically significantly responsible for sixty seven per cent of the variance of Pediastrum occurrence in Finnish Lapland (WесKSTRÖM et al. 2009). On the contrary, nitrate and orthophosphate concentrations were not statistically significantly correlated with Pediastrum in the present study. The concentrations were determined with colorimetric tests giving values at discrete levels. Such values are more difficult for interpretation than continuous values.

In the present study, P. boryanum and $P$. duplex varieties showed varied ecological preferences, which agrees with literature data (e.g. KOMÁREK \& JANKOVSKÁ 2001; Tell 2004; WeCKSTRÖM et al. 2009).

Among them, a few P. boryanum varieties (boryanum, forcipatum and pseudoglabrum) and $P$. duplex var. duplex were positively correlated with indicators of higher trophy (conductivity, orthophosphates or nit- 
rates). According to KomÁReK \& JANKOvskÁ (2001), $P$. boryanum var. boryanum and $P$. boryanum var. pseudoglabrum occur in a wide range of various eutrophic and usually slightly alkaline freshwaters; the little known $P$. boryanum var. forcipatum is more thermophilic, occurring in tropical and warmer regions of the temperate zones. More recent findings of the P. boryanum varieties are from oligotrophic and dystrophic subarctic lakes in Finland (WECKSTRÖM et al. 2009) and Polish coastal lakes with increased chloride concentration (KowALSKa \& WoŁowsKi 2010b). P. duplex var. duplex showed a clear affinity for eutrophic ponds and lakes in the study of LENARCZYK (2014), whereas KoMÁREK \& FOTT (1983) stated that the taxon is probably cosmopolitan in various types of water bodies.

Three other P. boryanum varieties (cornutum, longicorne and perforatum) were positively correlated with lower trophy. On the contrary, previous studies indicated that $P$. boryanum var. cornutum occurs in eutrophic waters (KOMÁREK \& JANKOVSKÁ 2001). In the study conducted in Finnish Lapland, P. boryanum var. longicorne dominated oligotrophic high altitude lakes with higher $\mathrm{pH}$ and conductivity (WECKSTRÖM et al. 2009). However, it must by pointed out that in the lakes included in that study, the highest $\mathrm{pH}$ value was

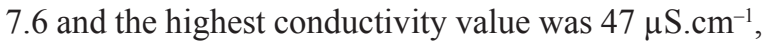
whereas in the present study such values were among the lowest. KOMÁREK \& FOTT (1983) mentioned that the taxon is distributed in clear lakes, whereas KomÁREK \& JANKOVSKÁ (2001) stated that its occurrence is restricted to peaty waters and it probably has a boreo-alpine distribution. However, it is also known from warm regions of Argentina (Tell 2004) and in Poland was it found in mesotrophic, eutrophic and humoeutrophic lakes (LENARCZYK 2014). The observed occurrence of P. boryanum var. perforatum is in agreement with previous records from clear lakes and ponds (KOMÁREK \& JANKOVSKÁ 2001). The cluster analysis revealed that the taxon is typical of mesotrophic to eutrophic water bodies which have alkaline $\mathrm{pH}$, medium conductivity and low nutrient concentrations (Fig. 2).

Pediastrum angulosum var. angulosum was negatively correlated with conductivity in the present study. The lakes where the taxon was found are described as oligo/mesotrophic and humoeutrophic by LENARCZYK (2014). The cluster analysis showed that it is typical of lakes with a low trophic status (Fig. 2), what confirms the previous findings of WECKSTRÖM et al. (2009). There are discrepancies in the preferences of $P$. angulosum var. angulosum with respect to $\mathrm{pH}$. KomÁREK \& JANKOVSKÁ (2001) stated that it is rather alkaliphilous and does not occur in peaty and acidic waters, whereas PARRA (1979) described it as occurring mostly in slightly acidic and neutral waters. WECKSTRÖM et al. (2009) found its greatest abundance in a slightly acidic lake having a $\mathrm{pH}$ of 6.4 . In the present study, it was found in alkaline waters ( $\mathrm{pH} 7.4-8.2)$, but no correlation between $\mathrm{pH}$ and its occurrence was observed (Fig. 3).
In one of the lakes where $P$. angulosum var. angulosum was found two other taxa, P. integrum var. integrum and $P$. privum, were observed. The brown water colour, the relatively high $\mathrm{pH}$ (8.2) and medium conductivity $\left(148 \mu \mathrm{S} . \mathrm{cm}^{-1}\right)$ values indicate that the lake is humoeutrophic, midway between dystrophic and harmonic (GÓRNIAK 1996). KOMÁREK \& JANKOVSKÁ (2001) stated that $P$. integrum var. integrum occurs rarely in clear, usually oligotrophic to dystrophic swamps and on rocky walls with dripping water. On the contrary, $P$. privum seems to be more adaptable to various environmental conditions. Most records of this species are from clear northern lakes, dystrophic water bodies and peat bogs (KowALSKA \& WoŁowsKi 2010a), but some are from eutrophic ponds (An et al. 1999), a river (HindÁK \& HindákovÁ 2004; Hindák \& HindÁKová 2008) and the Baltic sea (HÄLlFors 2004) as well.

Three taxa were positively correlated with high $\mathrm{pH}$ values in the present study. Among them, $P$. alternans and $P$. kawraiskyi were found only in eutrophic coastal lakes with $\mathrm{pH}$ 8.9-9.6, whereas $P$. duplex var. rugulosum was found in meso/eutrophic and humoeutrophic water bodies with $\mathrm{pH}$ 8.2-9.3. Similarly, previous findings of $P$. alternans in Poland and Denmark were from eutrophic lakes with $\mathrm{pH}$ 8-9 (NygAard 1949; Pasztaleniec \& Poniewozik 2004). Komárek \& JANKOVSKÁ (2001) presumed that it requires large oligotrophic to mesotrophic lakes which are cold and clear. Similar ecological preferences were given by the authors for P. kawraiskyi. WECKSTRÖM et al. (2009) stated that $P$. kawraiskyi dominates high-altitude Finnish lakes with higher $\mathrm{pH}$, but the maximum $\mathrm{pH}$ in the analyzed data set was only 7.6. In Argentina, it was found only in cold and mountainous regions (Tell 2004). However, numerous records of $P$. kawraiskyi from Poland comprising paraoligotrophic and eutrophic, as well as hypertrophic and polluted habitats (LENARCZYK 2014) indicate that the species is quite tolerant to varying ecological conditions. According to PARRA (1979), P. duplex var. rugulosum occurs in neutral to slightly alkaline waters. KOMÁREK \& JANKOVSKÁ (2001) stated that it has been occurring in large numbers since the Late Glacial and has adapted to increasing eutrophication of water biotopes.

Both $P$. simplex varieties, simplex and echinulatum, which were positively correlated with conductivity, carbonate hardness and nutrient concentration, occurred only in eutrophic lakes and ponds (Table 1). In contrast, KOMÁREK \& JANKOVSKÁ (2001) stated that the species occurs mainly in mesotrophic and not very polluted water bodies. However, the difference in ecological preferences may result from the fact that these data consider the species as a whole, whereas only two from seven varieties were analyzed in the present study. According to Coesel \& Krienitz (2008), P. simplex belongs to the so called, invading species", which previously were "tropical/subtropical", but increased their distribution area in the last decades and are encounte- 
red regularly in the temperate zone nowadays.

The weak correlations between the occurrence of $P$. tetras and all environmental variables measured indicate that the species is indifferent to changes in habitats. Such indifference was also stated by PARRA (1979). The species occurs in both mesotrophic and eutrophic lakes, ponds and in swampy water biotopes (MatUŁA 1995; KOMÁREK \& JANKOVSKÁ 2001). However, studies in Finnish Lapland showed that it is restricted to more dystrophic low altitude lakes (WECKSTRÖM et al. 2009). KomÁreK \& JANKOVSKÁ (2001) pointed out that $P$. tetras probably occurs in several various morphotypes which can have geographically delimited areas of distribution. Recent phylogenetic studies revealed that P. tetras (as Stauridium tetras) is paraphyletic, with P. privum (as $S$. privum) nested within it (McManus \& Lewis 2011). Nevertheless, detailed morphological studies on strains from distant localities are necessary to detect potential separate taxonomic units within $P$. tetras.

The present study gives new insights into ecological preferences of Pediastrum. The study can be useful to interpret paleoenvironmental data since at least some Pediastrum taxa and communities show a bioindicative potential in lowland and upland waters of the northern temperate zone. This potential results from the fact that the occurrence of particular Pediastrum taxa and communities is influenced by different environmental conditions. There are taxa characteristic of low or high trophy, like $P$. angulosum and $P$. boryanum varieties, connected with high $\mathrm{pH}$, like $P$. kawraiskyi, and typical of brackish waters, like $P$. alternans and $P$. musteri. The present study also shows that the number of taxa is lowest in freshwaters with low trophy and highest in eutrophic brackish lakes. Moreover, NEUSTUPA \& HODAČ (2005) demonstrated that not only the occurrence of Pediastrum but also its morphology depends on environmental conditions. They assumed that Pediastrum taxa can be convenient model organisms for investigating the interactions between environment and morphology in palaeolimnology and freshwater biomonitoring. Further morphometric analysis of cells and coenobia in the gradients of individual variables could be useful for detailed inference about environmental changes.

\section{ACKNOWLEDGEMENTS}

The author is grateful to the anonymous reviewers for valuable remarks on the manuscript. This work was funded in part by the Polish Ministry of Science and Higher Education for 2008-2010 (grant no. N N303 070534) and by the statutory fund of the W. Szafer Institute of Botany of the Polish Academy of Sciences.

\section{REFERENCES}

An, S.S.; Hegewald, E. \& Jeon, S.L. (1999): Pediastrum privum (Printz) Hegewald new to Korea. - Algae 14: 83-85.
Blokker, P.; Schouten, S.; van den Ende, H.; de Leeuw, J.W.; Hatcher, P.G. \& Sinninghe Damstê̂, J.S. (1998): Chemical structure of algaenans from the fresh water algae Tetraedron minimum, Scenedesmus communis and Pediastrum boryanum. - Org. Geochem. 29: $1453-1468$.

Buchheim, M.; Buchheim, J.; Carlson, T.; Braband, A.; HePperle, D.; Krienitz, L.; Wolf, M. \& Hegewald, E. (2005): Phylogeny of the Hydrodictyaceae (Chlorophyceae): inferences from rDNA data. - J. Phycol. 41: 1039-1054.

Burchardt, L.; Messyasz, B.; Owsianny, P.M.; Pelechata, A. \& STEFANIAK, K. (2003): Chlorococcalean algae from four lakes in the Slowinski National Park (northern Poland). - Biologia 58: 467-474.

Coesel, P.F.M. \& Krienitz, L. (2008): Diversity and geographical distribution of desmids and other coccoid green algae. - Biodivers. Conserv. 17: 381-392.

Comas GonzÁlez, A. (2005): Pediastrum aniae sp. nova, eine in den Tropen gefundene Art und ihre Beziehungen zu P. kawraiskyi Schmidle und anderen ähnlichen Sippe (Hydrodictyaceae, Chlorophyceae). - Algological Studies 116: 49-65.

Comas González, A. \& Perez, M.D. (2002): Chlamydophyceae (Chlorophyceae) from Merin lagoon (BrazilUruguay, South America) with special references to the family Botryococcaceae. - Algological Studies 145: 49-65.

Comas González, A.; Perez, M.C. \& Rams, R. (2006): Pediastrum willei nom. et sp. nov. (Chlorophyta, Neochloridales) from the Ebro river (Spain) and its relations to P. muticum Kutz. sensu Brunnthaler 1915 pro parte. - Algological Studies 120: 5-13.

GóRNIAK, A. (1996): Typologia i aktualna trofia jezior WPN. - In: Górniak, A. (ed.): Jeziora Wigierskiego Parku Narodowego. Aktualna jakość i trofia wód. - pp. 128-140, Wydawnictwo Uniwersytetu w Białymstoku, Białystok.

HAmmer, O.; Harper, D.A.T. \& Ryan, P.D. (2001): PAST: Paleontological statistics software package for education and data analysis. - Palaeontol. Electron. 4: $1-9$.

Hällfors, G. (2004): Checklist of Baltic Sea phytoplankton species (including some heterotrophic protistan groups). - HELCOM Balt. Sea Environ. Proc. 95: $1-208$.

HindÁk, F. \& HindÁKovÁ, A. (2004): Diversity of phytoplankton of the Morava and Danube rivers in Bratislava (W Slovakia) in 2003. - Bull. Slov. Bot. Spolecn., Bratislava 26: 9-17.

HindÁK, F. \& HindÁKOVÁ, A. (2008): Morphology and taxonomy of some rare chlorococcal algae (Chlorophyta). - Biologia 63: 777-786.

IZAGUiRRE, I. \& VinocuR, A. (1994): Algal assemblages from shallow lakes of the Salado River Basin (Argentina). - Hydrobiologia 289: 57-64.

JANKovskÁ, V. \& KoMÁrek, J. (1982): Das Vorkommen einiger Chlorokokkalalgen in böhmischen Spätglazial und Postglazial. - Folia Geobot. Phytotax. 17: $165-195$.

JANKovskÁ, V. \& KomÁReK, J. (1995): Pediastrum orientale from subfossil layers. - Folia Geobot. Phytotax. 30: 319-329.

Jena, M.; Bock, C.; Behera, C.; Siba, P.; Adhikary, S.P. \& KriEnITZ, L. (2014): Strain survey on three continents 
confirms the polyphyly of the genus Pediastrum (Hydrodictyaceae, Chlorophyceae). - Fottea 14: 63-76.

Komárek, J. \& Fott, B. (1983): Chlorophyceae (Grünalgen), Ordnung: Chlorococcales. - In: Huber-Pestalozzi, G. (ed.): Das Phytoplankton des Süßwassers. - 1044 pp., E. Schweizerbart'sche Varlagsbuchhandlung (Nägele u. Obermiller), Stuttgart.

KomÁrek, J. \& JANKovská, V. (2001): Review of the green algal genus Pediastrum: implication for pollen-analytical research. - Bibl. Phycol. 108: 1-127.

Kondracki, J. (1994): Geografia Polski. Mezoregiony fizyczno-geograficzne. - 340 pp., PWN, Warszawa.

Kondracki, J. (2002): Geografia regionalna Polski. - 444 pp., PWN, Warszawa.

Kowalska, J. \& Wolowski, K. (2010a): Pediastrum privum (Printz) Hegewald in Lake Małe Zmarłe, northern Poland. - Oceanol. Hydrobiol. Stud. 39: 137-143.

Kowalska, J. \& Wolowski, K. (2010b): Rare Pediastrum species (Chlorophyceae) from Polish coastal lakes. - Acta Soc. Bot. Pol. 79: 225-233.

LenarczyK, J. (2014): The algal genus Pediastrum Meyen (Chlorophyta) in Poland. - 104 pp, Institute of Botany PAS, Kraków.

MatuŁA, J. (1995): Warunki troficzne glonów torfowiskowych na obszarze Dolnego Śląska. - Zeszyty Naukowe Akademii Rolniczej we Wrocławiu, 265. Rozprawy $135: 1-132$.

McManus, H. \& Lewis, L.A. (2011): Molecular phylogenetic relationships in the freshwater family Hydrodictyaceae (Sphaeropleales, Chlorophyceae), with an emphasis on Pediastrum duplex. - J. Phycol. 47: $152-163$

McManus, H.; Lewis, L.A. \& Schultz, E.T. (2011): Distinguishing multiple lineages of Pediastrum duplex with morphometrics and a proposal for Lacunastrum gen. nov. - J. Phycol. 47: 123-130.

Neustupa, J. \& Hodač, L. (2005): Changes in shape of the coenobial cells of an experimental strain of $\mathrm{Pe}$ diastrum duplex var. duplex (Chlorophyta) reared at different pH. - Preslia 77: 439-452.

Nielsen, H. \& Sørensen, I. (1992): Taxonomy and stratigraphy of late-glacial Pediastrum taxa from Lysmonsen, Denmark - a preliminary study. - Rev. Palaeobot. Palynol. 74: 55-75.

NygaARD, G. (1949): Hydrobiological studies on some Danish ponds and lakes. Part II: The quotient hypothesis and some new or little known phytoplankton organisms. - Kongel. Danske Vidensk. Selsk. Biol. Skr. 7: $1-293$.

Parra, O.O. (1979): Revision der Gattung Pediastrum Meyen (Chlorophyta). - Bibl. Phycol. 48: 1-186.

Pasztaleniec, A. \& Poniewozik, M. (2004): Pediastrum species (Hydrodictyaceae, Sphaeropleales) in phytoplankton of Sumin Lake (Łęczna-Włodawa Lakeland). - Acta Soc. Bot. Pol. 73: 39-46.

Sarmaja-Korjonen, K.; Seppänen, A. \& Bennike, O. (2006): Pediastrum algae from the classic late glacial Bølling Sø site, Denmark: response of aquatic biota to climate change. - Rev. Palaeobot. Palynol. 138: 95-107.

Sebestyén, O. (1968): Remains of Pediastrum kawraiskyi Schmidle (Chlorophyta, Protococcales) in the sediments of Lake Balaton. - Annales Instituti Biologici (Tihany) Hungaricae Academiae Scientiarum 35: 203-226.

Strzelecki, J. \& PóŁtoraK, T. (1971): Plankton przymorskie- go jeziora Gardno w okresie letnim. - Acta Hydrobiol. 13: 269-294.

Sulek, J. (1969): Taxonomische Übersicht der Gattung $P e-$ diastrum Meyen. - In: Fotт, B. (ed.): Studies in Phycology. - pp. 197-261, Publishing House of the Czechoslovak Academy of Sciences, Praque.

ŚWięta-Musznicka, J.; Latalowa, M.; Szmeja, J. \& BADURA, M. (2011): Salvinia natans in medieval wetland deposits in Gdańsk, northern Poland: evidence for the early medieval climate warming. - J. Paleolimnol. 45: 369-383.

Tell, G. (2004): Recent and fossil species of the genus $P e$ diastrum Meyen (Chlorococcales) from Argentina and their geographical distribution. - Algological Studies 112: 49-71.

Tell, G. \& Mataloni, G. (1990): Systematic studies on the Pediastrum kawraiskyi-musteri-patagonicum complex (Chlorophyta): two new species and morphological variations in two Patagonian lakes (Argentina). - Nova Hedwigia 50: 159-180.

TER BraAk, C.J.F. \& ŠMilauer, P. (2002): CANOCO Reference Manual and CanoDraw for Windows User's Guide. Software for Canonical Community Ordination (version 4.5). - Biometris, Wageningen and České Budějovice.

WACNIK, A. (2009): Vegetation development in the Lake Miłkowskie area, north-eastern Poland, from the Plenivistulian to the late Holocene. - Acta Palaeobot. 49: 287-335.

Weckström, K.; Weckström, J. \& Yliniemi, L.-M. (2009): The ecology of Pediastrum (Chlorophyceae) in subarctic lakes and their potential as paleobioindicators. - J. Paleolimnol. 43: 61-73.

Whiteside, M.C. (1965): On the occurrence of Pediastrum in lake sediments. - Journal of the Arizona Academy of Science 3: 144-146.

Whitney, B.S. \& Mayle, F.E. (2012): Pediastrum species as indicators of lake-level change in tropical South America. - J. Paleolimnol. 47: 601-615.

WoŁowski, K.; Obidowicz, A. \& Wawrzycka, I. (2002): Pediastrum species (Chlorophyceae) in Quaternary sediments of „Żabie Oko“ peat bog in the Tatra Mts. - Acta Palaeobot. 42: 51-61.

(C) Czech Phycological Society (2015)

Received December 11, 2014

Accepted April 10, 2015 